\title{
БЛОКЧЕЙН КАК ЧАСТЬ ЦИФРОВОЙ ЭКОНОМИКИ РОССИИ
}

Тхашоков М.X. ФГАОУ ВО СКФУ, ИСТиД (филиал) СКФУ, г. Пятигорск

В статье рассматриваются проблемы и перспективы применения технологии блокчейн в цифровой экономике России. Предлагается считать основной проблемой эффективность применения технологии блокчейн. Выполнен анализ основных достоинств и недостатков технологии блокчейн.

Ключевые слова: цифровая экономика, блокчейн, криптовалюта, биткоин, бизнес-модель, транзакция, платформа.

Блокчейн - это цифровая, децентрализованная и равномерно распределённая база данных.

Блокчейн часто объясняют на примере биткоина и истории денег. Но криптовалюты это только одна из областей применения блокчейна. Пока что самая масштабная, но есть основания предполагать, что не самая важная.

Блокчейн на сегодня - это самая загадочная технология, которая связана с «цифрой». В последнее время ряд экспертов предрекает полноценную замену в ближайшем будущем государственных функций на механизмы, выстроенные на базе технологии блокчейн [1].

Стоит отметить, что в цифровой экономике даже традиционно оффлайновые бизнесы трансформируются в онлайновые. Блокчейн создает рамки для формирования новой экосистемы бизнеса, а трансформационное обучение позволяет наполнять ее эффективными инновационными проектами.

О цифровой экономике говорится много, но не все еще понимают, что это такое, как ее внедрить и какой эффект она может принести. По словам омбудсмена по цифровой экономике, президента Seldon Илии Димитрова, цифровизация - это не просто перевод данных с бумаги на компьютер, а создание совершенно нового мира.

В интервью Marrket.org он объяснял, что «мы вошли в четвертую техническую революцию, где есть три главных термина: во-первых, всё цифры, во-вторых, новые материалы, в-третьих, новая система управления». Цифровая экономика - одна из производных этой революции, в ней нет места ВВП, потому что она - персонализированная и прогностическая [3].

Одной из главных технологий, которая должна стать частью цифровой экономики России и драйвером ее развития, безусловно, является блокчейн. Технология распределенных реестров еще молодая и многим непонятна, а у кого-то не вызывает доверия из-за криптовалюты и, в частности, биткоина, однако о преимуществах ее применения задумались и на государственном уровне, и в крупнейших корпорациях. 
Первым в России о блокчейне заговорил президент Сбербанка Герман Греф, который заявил о необходимости внедрения технологии в работу банка.

Сегодня Ассоциация «Финтех», в которую входят 14 крупнейших банков страны, разрабатывает собственный блокчейн «Мастерчейн» с использованием кодовой базы блокчейн-сети Ethereum, но с учетом требований к российской криптографии, процессу идентификации пользователей и безопасному процессу масштабирования.

Кроме того, в стране есть много талантливых блокчейн-разработчиков, которые создают либо свои собственные проекты, либо на основе других блокчейнов (Etherium, EOS, Corda R3, др.): как заявлял на форуме Blockchain Life в Санкт-Петербурге его организатор Сергей Хитров, российские программисты всегда были востребованы во всем мире, но разработчики блокчейна котируются как одни из самых профессиональных.

Советник председателя правления Внешэкономбанка Владимир Демин на том же форуме сказал, что у разработчиков в России есть проблема - они чтото придумывают, но не объясняют, как их проекты изменят жизнь людей. При этом реальные кейсы уже есть: например, в Новгородской области после запуска проекта на блокчейне по отслеживанию льготного лекарственного обеспечения город сэкономил 30 млн. рублей. Кроме того, говорит Демин, разработчики сами не всегда понимают, как внедрять их наработки в жизнь и где их применять.

Блокчейн занимает в процессах происходящей сегодня трансформации в экономике и в других сферах особое место. Deloitte объясняет почему организации в разных отраслях промышленности начали активно искать сценарии встраивания блокчейна в свои бизнес-модели. Корпорациям, банкам и правительствам неизбежно нужно повысить эффективность управленческих процессов, уйти от дорогостоящих, медленных или ненадежных транзакций и регистраций, внедрить новые модели кооперации. Возможна даже разработка принципиально новых информационных продуктов и сервисов, которые будут использовать технологию блокчейна. Правительства и корпорации активно инвестируют в стартапы блокчейна в надежде вписаться в новые реалии цифровой экономики. Блокчейн может в какой-то мере оправдать эти надежды, благодаря своим свойствам: криптография повышает безопасность транзакций, блочный реестр создает немыслимую ранее надежность хранения и подтверждения данных и одновременно их прозрачность. Smart-контракты изменяют саму природу важнейшей функции бизнеса - доверия. Теперь вместо привычных «агентов доверия» - регистраторов, нотариусов и чиновников, будут использоваться одноранговые консенсусные алгоритмы, нивелирующие транзакционные издержки, проволочки и даже коррупцию. Ставятся под сомнение перспективы существования в недалеком будущем самих «агентов доверия» и иных посредников [3].

Почему же эта замечательная технология не распространяется лавинообразно по всем отраслям экономики, сметая устаревшие бизнес-модели, как и их хозяев-ретроградов? Потому, популярно объясняет тот же Deloitte, что 
в отличие от, например, мобильного телефона, в части блокчейна важно понимать не только как это работает, а также почему это важно для дела. Например, Smart-контракт на Ethereum успешно прошел логистический эксперимент с поставкой груза из США в Австралию, но миллионы поставок в мире продолжают работать по старой схеме, управляемой статьей Incoterms и L/C. Как, впрочем, и основной объем трансграничных банковских переводов делается безнадежно устаревшей системой SWIFT. Проведенный анализ мнения ведущих специалистов о блокчейне, показал, что многие специалисты, пока скептично относятся к этой технологи и говорят о неготовности существующей инфраструктуры принять блокчейн в данный момент времени из-за необходимости привязки новых бизнес-моделей $~$ действующим отраслевым стандартам и руководствам. Нужно понимать, что в отрасли, наиболее контролируемые правительством и внутренними стандартами сложнее внедрять новые технологии [1].

Также, стоит отметить, что по словам Демина, несмотря на явные плюсы технологии, существующие блокчейны пока что не способны закрыть потребности государственного сектора, в первую очередь из-за низкой скорости транзакций. Между тем, высокоскоростной и высокопроизводительный блокчейн уже изобретен, и именно в России.

Компания b41 Blockchain Development, центральный офис которой находится в Екатеринбурге (и дополнительный в Москве), создала Nodes Plus Blockchain - программную платформу для промышленных решений на основе распределенного реестра, скорость в которой во время нагрузочных тестов превзошла 100 тыс. транзакций в секунду (TPS). И это не предел: масштабируемость зависит от количества компьютеров в сети. Для сравнения: скорость блокчейна биткоина - несколько транзакций в секунду, скорость платежных систем VISA и MasterCard - 25 тыс.

По словам главного разработчика и исполнительного директора b41Blockchain Development Олега Сивакова, по сути, им удалось создать промышленный стандарт. В условиях промышленного применения Nodes Plus один из немногих блокчейнов, способных обработать огромные массивы данных, генерируемых ІоТ-устройствами, обеспечивая при этом должный уровень безопасности и децентрализации.

При этом сферы применения не ограничиваются промышленностью. На базе платформы может быть реализована практически любая бизнес-логика за счет высокой конфигурируемости и инновационных возможностей, таких как, например, сервер кастомных программных библиотек. Также в Nodes Plus реализован весь функционал, присущий блокчейнам нового поколения: смартконтракты, произвольно контролируемый механизм консенсуса и другое.

При этом блокчейн нового поколения гарантирует защиту и неизменность информации. Разработчики научились делать на нем защищенные сайты (в том числе для СМИ), которые невозможно взломать или «уронить» DDoS-атаками. NodesPlus может применяться для проектов по цифровизации, стать базой данных для фермы искусственного интеллекта, решить задачу цифрового 
резидентства предприятия и личности, полностью избавив всех от бумажных носителей [2].

Команда уже делает пилотные проекты для ЖКХ и одной из школ Екатеринбурга, для логистики и медицинской сферы; активно ищет партнеров среди бизнеса и госсектора России и других стран мира.

\section{Список литературы}

1. Генкин, А. Блокчейн. Как это работает и что ждет нас завтра / А. Генкин. - М.: Альпина Паблишер, 2018. - 804 с.

2. Лелу, Лоран Блокчейн от А до Я. Все о технологии десятилетия / Лоран Лелу. - М.: Эксмо, 2017. - 179 с.

3. Скиннер, Крис ValueWeb. Как финтех-компании используют блокчейн и мобильные технологии для создания интернета ценностей / Крис Скиннер. Москва: Машиностроение, 2016. - 203 с. 